\title{
FUNKCJA RODZAJNIKA W OKREŚLANIU ADRESATA NORMY PRAWNEJ W HISZPAŃSKIM KODEKSIE CYWILNYM
}

\author{
Anna NOWAKOWSKA-GLUSZAK, dr \\ Uniwersytet Śląski, Instytut Języków Romańskich i Translatoryki, Zakład Hispanistyki \\ ul. Grota Roweckiego 5m 41-205 Sosnowiec \\ anna.nowakowska-gluszak@us.edu.pl
}

\begin{abstract}
Abstrakt: Celem artykułu jest pokazanie sposobu, w jaki kategorie prawne mogą determinować funkcjonowanie języka $w$ tekstach prawnych. Jest on jednocześnie propozycją spojrzenia na tekst prawny z perspektywy lingwistyki kulturowej.

Autorka dokonuje analizy struktury syntagmy nominalnej wyrażającej adresata normy prawnej w wybranych artykułach hiszpańskiego kodeksu cywilnego, by następnie określić czynniki determinujące użycie rodzajnika. W tym celu przedstawia tradycyjne podejście do tematu, dochodzi jednak do wniosku, że, by skutecznie opisać użycie rodzajnika w tekstach prawnych, należy uwzględnić strukturę i właściwości normy prawnej, zwłaszcza jej ogólny i abstrakcyjny charakter.

W swojej analizie opiera się na założeniach językoznawstwa kulturowego, przede wszystkim pojęciu językowego obrazu świata, łącząc je, zgodnie z koncepcją J. Wilk-Racięskiej, z elementami gramatyki o podstawach semantycznych. Dochodzi w ten sposób do wniosków pozwalających wyjaśnić nie tylko jak stosowany jest rodzajnik w analizowanych tekstach, ale, przede wszystkim, dlaczego, co, jej zdaniem, może mieć istotne znaczenie m. in. w badaniach translatologicznych.
\end{abstract}

\section{THE FUNCTION OF ARTICLES IN DETERMINING THE ADDRESSEE OF A LEGAL RULE IN THE SPANISH CIVIL CODE}

\begin{abstract}
The aim of the article is to present how the legal categories can determine the use of natural language in the legal discourse. It is, at the same time, an example of how we can employ the tools of cultural linguistics in Legal Linguistics.

The author analyzes nominal syntax structures expressing normative subject in the Spanish Civil Code and then she indicates the factors which might determine the use of the article. At the beginning she presents the traditional point of view and concludes that it is not able to explain effectively the selection of articles in the legal text, because it does not take into consideration the structure and properties of the legal norm, especially its abstract and general character.

That is why she proposes to make an analysis based on the assumptions of the cultural linguistics, especially the concept of worldview, and of the grammar on semantic base, according to the proposition of J. Wilk-Racięska, which allows for the introduction of same elements of the theory of law into the philological description, and, consequently, make it more efficient.
\end{abstract}

Słowa kluczowe: norma prawna, język prawny, adresat normy prawnej, funkcja rodzajnika w tekście prawnym 


\section{Wstęp}

Choć popularność języka hiszpańskiego w Polsce stale rośnie, a kontakty kulturowe $\mathrm{i}$ handlowe rozwijają się coraz bardziej dynamicznie, w zakresie badań nad hiszpańskim językiem prawa w Polsce do tej pory zrobiono niewiele.

\section{Badania nad hiszpańskim językiem prawa w Polsce}

Sytuacja ta przekłada się bezpośrednio na literaturę specjalistyczną. Jeśli chodzi o dostępne w Polsce pozycje, należy niewątpliwie wymienić słownik terminologii prawniczej autorstwa Mieczysława Komarnickiego, Igora Komarnickiego oraz Elżbiety Komarnickiej „Diccionario de terminología jurídica” (2005, 2007), oraz dwujęzyczną pozycję Marii Supery-Markowskiej: „Zarys prawa hiszpańskiego i prawa polskiego” (2009), która jednak praca o charakterze naukowym nie jest; pisana przez i raczej dla prawników, problemy językowe traktuje w sposób drugorzędny.

Językoznawczy punkt widzenia reprezentuje natomiast rozprawa doktorska Joanny Nowak z 2011 roku, w której autorka porównuje struktury deontyczne w polskim i hiszpańskim kodeksie cywilnym. Praca w momencie przygotowania niniejszego tekstu nie została jeszcze opublikowana.

Fakt, że język hiszpański w Polsce jest opisywany głównie przez prawników nie jest niczym wyjattkowym. Według Margarity Hernando de Larramendi Martínez, badaczki hiszpańskiego języka prawa oraz autorki licznych podręczników, ,(..) hiszpański język prawa w Hiszpanii był analizowany prawie wyłącznie przez znawców prawa, którzy w krytyczny sposób opisywali jego użycie i niejasność. Większość istniejących opisów autorstwa prawników ma charakter mea culpa i w nieznacznym stopniu skupia się na czynnikach interesujących $\mathrm{z}$ punktu widzenia nauczania hiszpańskiego jako języka obcego (...)” (2001). W konsekwencji opis języka prawa ogranicza się często do opisu terminologii i frazeologii specjalistycznej, gatunków tekstowych, ewentualnie pewnych tendencji syntaktycznych i stylistycznych. I tak Enrique Alcaraz Varó i Brian Hughes w swojej książce El español jurídico $(2002,16)$ jako cechy definiujące hiszpański język prawa wymieniają:

(i) Specyficzne słownictwo, stanowiące jego podstawę;

(ii) Pewne specyficzne tendencje syntaktyczne i stylistyczne;

(iii) Określone, właściwe prawu, gatunki tekstowe

Podobne stanowisko zajmują inni badacze; w skrajnym przypadku odrzuca się koncepcję języka prawnego jako takiego, zakładając istnienie wyłącznie terminologii specjalistycznej. Trudno zakwestionować ważkość terminologii specjalistycznej i wkład, jaki w jej analizę i opis wnoszą sami prawnicy, wydaje się jednak, że język prawa ma o wiele bardziej złożony charakter.

Aktualny stan rzeczy, patrząc z perspektywy języka polskiego, prowadzi do dwóch wniosków: a) w badaniach nad hiszpańskim językiem prawa dominuje prawniczy punkt widzenia; b) istniejący stan badań nie uwzględnia specyfiki polskiego odbiorcy, różnic zarówno prawno-kulturowych jak i językowych. Oznacza to konieczność stworzenia warsztatu naukowego, który, z jednej strony, uwzględniłby naszą perspektywę, a z drugiej, 
„uwolnił” badania językoznawcze, mówiąc nieco przesadnie, spod tyranii prawników. Innymi słowy, chodzi o taki opis języka hiszpańskich aktów normatywnych, dzięki któremu polski student/ thumacz będzie wiedział, jakie konstrukcje go tworzą i dlaczego; zawierający elementy teorii prawa, nie zaś odwrotnie.

\section{Językowy obraz świata $w$ tekstach prawnych}

Propozycja, którą pragniemy przedstawić, jest próbą opisu języka prawnego w kategoriach językoznawstwa kulturowego. Opiera się na założeniu o istnieniu w tekstach prawnych specyficznej wizji świata zdeterminowanej, z jednej strony kategoriami pojęciowymi określonego języka - w tym przypadku hiszpańskiego - a z drugiej danym systemem prawa będącego odzwierciedleniem doświadczeń i systemu wartości określonej wspólnoty. Językowy obraz świata rozumiemy tu za R. Tokarskim, cytowanym przez Renate Grzegorczykowa, jako: „Zbiór prawidłowości zawartych w kategorialnych związkach gramatycznych (fleksyjnych, słowotwórczych i składniowych) oraz w semantycznych strukturach leksyki, pokazujących swoiste dla danego języka sposoby widzenia poszczególnych składników świata, panujących w nim hierarchii i akceptowanych przez społeczność językową wartość" (Grzegorczykowa 2001, 163), zaś koncepcja prawnego obrazu świata została szczegółowo omówiona w innych artykułach autorki niniejszego tekstu (por. Nowakowska-Głuszak 2011 i 2012).

Jeśli chodzi o przyjętą metodologię badań, w znacznej mierze opiera się na propozycji Joanny Wilk-Racięskiej (2009), łączącej w badaniach nad językiem hiszpańskim gramatykę o podstawach semantycznych $\mathrm{z}$ elementami lingwistyki kulturowej. Badaczka ta wychodzi z założenia, że, by skutecznie opisać inny język, należy przekroczyć granice narzucone przez własną wizję świata (czy to w wymiarze makro czy mikro) i określić, między innymi za pomocą dekompozycji semantycznej, zbiór pojęć konstytutywnych dla drugiego języka. Wprowadza jednocześnie termin „pojęć podstawowych” (conceptos básicos), ściśle związanych z funkcjonowaniem człowieka jako istoty społecznej, zakorzenionych i intuicyjnie zrozumiałych dla członków danej wspólnoty, choć, w przeciwieństwie do pojęć prostych, ulegających dekompozycji semantycznej.

Podobna sytuacja istnieje, naszym zdaniem, w tekstach (a zatem i języku) prawnych: odzwierciedlają one pewien obraz świata, posługując się zbiorem kategorii niedostępnych dla normalnego człowieka, przez co uznawane są za trudne i niezrozumiałe. Cechy formalne mają tym samym charakter wtórny.

By zatem dokonać skutecznej analizy języka prawa należy, w pierwszej kolejności, określić zbiór pojęć dla niego konstytutywnych a następnie za ich pomocą dokonać opisu. Ze wstępnej analizy wynika, że podstawową kategorią prawnego obrazu świata jest norma prawna. Należy rozumieć ją w dwojaki sposób: jako pewną strukturę logiczno-semantyczną i jako konkretną zasadę postępowaniu. W tym pierwszym znaczeniu wydaje się mieć charakter uniwersalny i, naszym zdaniem, przejawia się głównie na poziomie syntaktycznym tekstu prawnego. 


\section{Kategoria normy prawnej}

Norma prawna w hiszpańskiej literaturze tematu (por. Lasarte 2009) definiowana jest w kategoriach struktury dwuelementowej, składającej się z supuesto de hecho, czyli pewnej sytuacji (zazwyczaj konfliktu) wymagającej regulacji i z consecuencia jurídica, czyli nakazu lub zakazu odnoszącego się do niej.

Supuesto de hecho (supuesto normativo) ma zawsze charakter hipotetyczny i wyraża sytuację, której dotyczy norma. Może to być działanie ludzkie lub określona sytuacja. Consecuencia jurídica wyraża to, co powinno nastapić (deber ser).

Z językowego punktu widzenia Zieliński (2002) wskazuje na cztery elementy syntaktyczne normy prawnej, tj. adresat normy, okoliczności, nakaz lub zakaz, zachowanie, przy czym nie zawsze wyrażone są w sposób eksplicytny. Podział przez niego proponowany stanowi punkt wyjścia w naszej analizie, przy czym elementy normy prawnej traktujemy jako kategorie semantyczne, których struktura wewnętrzna ma swoje odzwierciedlenie na poziomie formalnym tekstów prawnych. By ją określić, musimy odnieść się do teorii prawa.

A zatem przepisy prawa mają ,charakter generatywny i abstrakcyjny, wyrażaja określone normy zachowania, których nieprzestrzeganie jest zagrożone zastosowaniem przymusu państwowego" (Nowacki i Tabor 2000, 265). Skierowane są do adresatów prawa, przy czym ,adresatami prawa są wszystkie bez wyjątku podmioty prawa, z tym, że nie wszystkie przepisy dotyczą wszystkich podmiotów prawa. Przepisy same określaja klasy podmiotów, do których kierują swe postanowienia” (Nowacki i Tabor 2000, 40). Ów generatywny i abstrakcyjny charakter jest, naszym zdaniem, kluczowy w analizie użycia rodzajnika (i nie tylko) w hiszpańskich tekstach prawnych.

\section{Funkcja rodzajnika w wyrażaniu adresata normy}

Jak wiadomo, rodzajnik, zwłaszcza dla rodzimych użytkowników języka takiego jak polski, jest kwestią niezwykle problematyczna. Obszerność literatury tematu, zarówno teoretycznej jak i praktycznej, potwierdza ten fakt.

\subsection{Status rodzajnika $w$ języku hiszpańskim}

W języku hiszpańskim rodzajniki powstały w wyniku ewolucji zaimków wskazujących i zaliczane są do kategorii determinantów (adjetivos determinativos), których podstawową funkcją jest „wyróżnianie obiektów oraz ich ilości” (por. Moliner 1994).

W hiszpańskim mamy dwa typy rodzajników: określony (definido, determinado): el, ella, los, las; i nieokreślony (indefinido, indeterminado): un, una. Niektórzy badacze wskazuja jeszcze tzw. rodzajnik zerowy (por. Pawlik 2003, 52). Ich funkcję i użycie definiuje się w kategoriach określoności i nieokreśloności oraz aktualizacji wyrażeń rzeczownikowych: „Rodzajnik zawsze wyraża kategorię określoności i nieokreśloności charakteryzująca referenta syntagmy nominalnej. Jednocześnie odnosi się do opozycji między rzeczami 
postrzeganymi jako konkretne jednostki a tymi, o których myślimy w kategoriach pewnego rodzaju czy gatunku" (Pawlik 2001, 48) ${ }^{8}$.

$\mathrm{Na}$ potrzeby niniejszej analizy i zgodnie $\mathrm{z}$ jej założeniami badawczymi, traktować będziemy rodzajnik jako jednostkę formalną języka używaną w funkcji semantycznej (por. Karolak 2001, 337).

\subsection{Rodzajnik w tekstach prawnych}

W literaturze specjalistycznej na temat hiszpańskiego języka prawa, rodzajnikowi nie poświęcono zbyt wiele uwagi. I tak Hernando Cuadrado opisując poziom morfosyntaktyczny hiszpańskich tekstów prawnych stwierdza: „rodzajnik [określony] często nadaje wartość generyczną wprowadzając rzeczowniki, które nie odnoszą się do indywidualnych osób ani konkretnych rzeczy” (2003, 15), i „rodzajnik nieokreślony un, wraz $\mathrm{z}$ czasownikiem w formie futuro imperfecto de indicativo czasami wskazuje, że referent syntagmy lub grupy nominalnej, którą poprzedza, nie istnieje w momencie formułowania wypowiedzi, ale może zaistnieć w przyszłości” (2003, 15-16). Opis ten, z oczywistych powodów, wydaje się mało satysfakcjonujący z perspektywy polskiego odbiorcy.

Spróbujmy przeanalizować problem na przykładzie wybranych artykułów z hiszpańskiego kodeksu cywilnego:

1. $\quad$............ extranjero menor de dieciocho años adoptado por un español adquiere, desde la adopción, la nacionalidad española de origen. (Art. 19)

2. $\quad$.............. hijo, al alcanzar la mayor edad, podrá solicitar que se altere el orden de los apellidos. (Art. 109)

3. $\quad$........... menor no emancipado ejercerá la patria potestad sobre sus hijos con la asistencia de sus padres y, a falta de ambos, de su tutor; en casos de desacuerdo o imposibilidad, con la del Juez. (Art. 157)

4. Si..................... usuario consumiera todos los frutos de la cosa ajena, o el que tuviere derecho de habitación ocupara toda la casa, estará obligado a los gastos de cultivo, a los reparos ordinarios de conservación y al pago de las contribuciones, del mismo modo que el usufructuario. (Art. 527)

Co przemawia za użyciem rodzajnika określonego, nieokreślonego bądź zerowego w powyższych zdaniach? Jakim kryterium powinien kierować się nasz student? By odpowiedzieć na to pytanie, oprzemy się na podręczniku uniwersyteckim Selección de problemas de gramática española, skierowanym, jak zauważa w przedmowie sam autor, Janusz Pawlik, do neofilologów. Skupimy się na syntagmach nominalnych (SN) reprezentowanych przez nasze przykłady, tj. prostych lub złożonych, w których rzeczownik ma liczbę pojedynczą jest nazwą ogólną

\footnotetext{
${ }^{8}$ Wszystkie tłumaczenia z języka hiszpańskiego wykonała autorka.
} 
o charakterze policzalnym. Jest to struktura, która w hiszpańskim kodeksie cywilnym dość często wyraża adresata normy prawnej.

\subsection{Zasady użycia rodzajnika $w$ języku hiszpańskim}

Jak wskazuje polski hispanista, Pawlik, w przypadku wartości generycznej zdania, często możemy w języku hiszpańskim użyć rodzajnika określonego (RO) bądź nieokreślonego $(\mathrm{RN})$ bez zmiany referencji:

Un/El hombre entregado a los estudios se cuida poco de las diversiones';

choć RN zazwyczaj wskazuje na każdy element ze zbioru (lektura dystrybucyjna), a RO zbiór jako całość (lektura globalna):

Para el hombre es importante ahorrar energía eléctrica (para la humanidad).

Para un hombre es importante vestirse bien (para un individuo).

Jak zauważa, „w zdaniach o charakterze zasad moralnych preferowane jest użycie rodzajnika niekreślonego generycznego, np.: Un soldado no teme a la muerte" (Pawlik 2001, 56), co nie oznacza, że nie można również użyć RO, zwłaszcza w konstrukcjach $\mathrm{z}$ czasownikiem modalnym. W tym przypadku powołuje się na przykłady z innych języków (francuski, niemiecki).

W przypadku referencji niegenerycznej, użycie rodzajnika jest ściśle związane z kategorią determinacji/ indeterminacji rzeczownika. Autor wskazuje, że „rzeczownik z RO oznacza, że jego referent jest znany dla nadawcy i odbiorcy; RN może odnosić się do obiektów nieznanych odbiorcy" (Pawlik 2001, 78). Ponadto RN i RZ aktualizuja rzeczownik jako „reprezentanta pewnego zbioru, identycznego z wszystkimi innymi należącymi do tego zbioru. W tym przypadku rzeczownik nie jest abstrakcyjny, jest konkretny, ale pozostaje niekreślony dla mówców, albo przynajmniej dla słuchacza, np. Ayer vi a una muchacha en el cine $(2001,81)$.

Jeżeli mamy do czynienia z SN złożoną, w skład której wchodzi zdanie podrzędne przymiotnikowe (oración adjetiva), RN wskazuje, że zdanie przymiotnikowe nie tyle identyfikuje, ile zawęża zakres znaczeniowy rzeczownika. Czasami, jeśli SN występuje w pozycji podmiotu, użyty jest rodzajnik określony, żeby wskazać na pewnych nieokreślonych reprezentantów danej grupy:

Los sacerdotes llevaron a China la moderna astronomía. (algunos sacerdotes)

Jeśli do rzeczownika dodajemy przymiotnik, można, bez zmiany referencji, opuścić rodzajnik:

(los) sacerdotes católicos... $(2001,86)$.

\footnotetext{
${ }^{9}$ Wszystkie przykłady zaczerpnięte z J. Pawlik (2001). 
To krótkie i, ze względu na charakter niniejszego artykułu, bardzo ogólne wprowadzenie wyraźnie pokazuje, że nie jest łatwo określić, jaki rodzajnik powinien zostać użyty w powyższych zdaniach; na których aspektach się skupić (rodzaj referencji, lektury, stopień złożoności syntagmy), by jednoznacznie określić i uzasadnić użycie tego a nie innego rodzajnika. Wynika to $\mathrm{z}$ faktu, że kategorie użyte do opisu języka nie uwzględniają specyfiki obrazu rzeczywistości wyrażanego w tekstach prawnych i, tym samym, kategorii, którymi posługuje się legislator, by prawo kodyfikować. I nie mamy tu na myśli treści konkretnych przepisów; chodzi o pewne złożone struktury pojęciowe, które pozwalają klasyfikować fakty zaistniałe w rzeczywistości i łączyć je za pomocą relacji przyczynowo-skutkowych.

Jak zatem rozwiązać problem rodzajnika w oparciu o koncepcję prawnego obrazu świata? Spójrzmy jeszcze raz na nasze przykład.

\subsection{Rodzajnik w SN określającej adresata normy prawnej}

Decydując, który rodzajnik powinien zostać użyty, dokonujemy analizy możliwych rozwiązań, bazując na naszej wiedzy o konkretnym języku naturalnym, w tym przypadku hiszpańskim, i zbiorze kategorii, które wyrażaja jego elementy (np. określoność). Tymczasem, okazuje się, że uwzględnienie dodatkowych kategorii, a konkretnie, kategorii prawnych, zwiększa efektywność opisu.

Jeśli przyjrzymy się przytoczonym fragmentom, zauważamy, że w każdym z nich interesująca nas SN wskazuje adresata normy. Wiemy z teorii prawa, że normy mają charakter abstrakcyjny i nie odnoszą się do konkretnych osób czy rzeczy, dlatego już na początku możemy wykluczyć referencję jednostkową. Dochodzimy tym samym do pierwszego wniosku: chcąc wybrać właściwy rodzajnik w SN, która w sposób eksplicytny wyraża adresata normy prawnej, musimy wybrać rodzajnik o charakterze generycznym.

Jak zatem zdecydować, czy lepszy będzie rodzajnik określony czy nieokreślony, skoro, jak wiemy, oba mogą tę wartość wyrażać? W tym momencie możemy oprzeć się na wspomnianej już teorii gramatyki o podstawach semantycznych, która, przypomnijmy, na gruncie języka hiszpańskiego rozwijana jest przez J. Wilk-Racięską (1995, 2009). Wyjaśnia ona użycie rodzajnika w kategoriach intensjonalnych, tzn. komunikowanej treści, za pomocą reguł zupełności/niezupełności intensjonalnej, pozostającej w ścisłym związku z kontekstem zewnętrznym, szczegółowym lub ogólnym: „Określoność/ nieokreśloność pojęć i nazw ogólnych należy zatem kalkulować z uwzględnieniem wartości pozycji, w których się je umieszcza” (Karolak 2001, 459). I znów, odnosząc się do prawnej koncepcji normy, musimy stwierdzić, że, ze względu na fakt, że ma ona charakter ogólny i abstrakcyjny, a sama sytuacja, którą reguluje (czyli ta, w której znajduje się adresat normy) charakter hipotetyczny, odrzucamy kontekst szczegółowy. Stwierdzamy tym samym, że nazwa ogólna określająca adresata normy musi być użyta w całym zakresie wyznaczanym przez jej treść (ekwiwalencja zakresu nazwy i kontekstu), co oznacza jej określoność. 
Deskrypcje określone, z zasady, mają dwie podstawowe cechy:

- mogą odnosić się prawdziwie do wszystkich (i każdego z osobna) obiektów przez nie nazwanych, przy czym w wymienionych wypowiedzeniach nie zostały użyte $\mathrm{z}$ intencja wyróżnienia żadnego z tych obiektów;

- wszystkie wypowiedzenia, w których zostały użyte, są atemporalne, co oznacza, że mogą zostać orzeczone prawdziwie zarówno w czasie przeszły, przyszłym, jak i teraźniejszym (Wilk-Racięska 2009, 133). Dodatkowo, w języku hiszpańskim użycie generyczne kolektywne, w przeciwieństwie do dystrybutywnego, wymaga rodzajnika określonego.

Nasze wnioski wydają się potwierdzać rodzajniki użyte w wyżej wymienionych przykładach: w każdym przypadku użyty został rodzajnik określony. Jak wynika ze wstępnie przeprowadzonej analizy tekstu hiszpańskiego kodeksu cywilnego podobna sytuacja ma miejsce również $\mathrm{w}$ innych artykułach.

\section{Wnioski końcowe}

Zaprezentowana, bardzo skrótowo i w sposób ogólny, analiza przykładów zaczerpniętych $\mathrm{z}$ hiszpańskiego kodeksu cywilnego dowodzi, że w tekstach prawnych na struktury semantyczno-syntaktyczne języka naturalnego nakładają się pewne kategorie prawne, które determinują ich użycie. Zależność taka zgodna jest z koncepcja językowego obrazu świata, która, przypomnijmy, zakłada, że struktury językowe odzwierciedlają specyficzny dla danej społeczności sposób widzenia rzeczywistości. Jeśli założymy, że prawo, samo w sobie, jest wyrazem specyficznego postrzegania rzeczywistości (bez wchodzenia w dyskusję, do jakiego stopnia jej ono wytworem pewnej wspólnoty, a do jakiego legislatorów), możemy przyjąć istnienie w tekstach prawnych tzw. ,prawnej wizji świata”.

Prawna wizja świata jest podzbiorem wewnątrz tej ogólnej, powstałym w wyniku nałożenia na nią pewnych ram prawnych. W konsekwencji, zmienia się system kategorii dla niej konstytutywnych, co musi znaleźć swój wyraz w opisie językoznawczym. I tak, jak mogliśmy zaobserwować, istotną z punktu widzenia kategorii językowych, a konkretnie hiszpańskiego rodzajnika jest kategoria normy prawnej i jej adresata (oraz pozostałych elementów) definiowana, między innymi, przez swój generyczny i abstrakcyjny charakter. Uwzględnienie tego faktu znacznie ułatwia i precyzuje opis języka prawa, z uwagi chociażby na fakt, że eliminuje, nierelewantne z punktu widzenia tegoż, kategorie, np. referencję jednostkową. 


\section{Bibliografia}

Alcaraz Varó, Enrique i Hughes, Brian. 2002. El español jurídico. Barcelona: Ariel.

Grzegorczykowa, Renata. 2001. Wprowadzenie do semantyki językoznawczej. Warszawa: PWN.

Hernando Cuadrado, Luis Alberto. 2003. El lenguaje jurídico. Madrid: Verbum.

Hernando de Larramendi Martínez, Margarita. 2001. Propuesta de estructuración y clasificación del léxico jurídico para su enseñanza. E/LE. Culturele. Revista informática de la Universidad de Barcelona, http://www. ub. edu/filhis/culturele/larramen. html (data dostępu 2 czerwca 2012 r.).

Karolak, Stanisław. 2001. „Jak thumaczyć coś, co nie istnieje”. W Od semantyki do gramatyki, Stanisław Karolak, 439-458. Warszawa: Slawistyczny Ośrodek Wydawniczy.

Karolak, Stanisław. 2001. „Status rodzajnika w gramatyce o podstawach semantycznych”. W Od semantyki do gramatyki, Stanisław Karolak, 337-360. Warszawa: Slawistyczny Ośrodek Wydawniczy.

Komarnicki, Mieczysław., Komarnicki Igor. 2005. Diccionario de Terminología Jurídica españolpolaco. Warszawa: Wydawnictwo C. H. Beck.

Komarnicki, Mieczysław, Komarnicki Igor, Komarnicka, Elżbieta, 2007. Diccionario de Terminología Jurídica polaco-español. Warszawa: Wydawnictwo C. H. Beck.

Lasarte, Carlos. 2009. Curso de derecho civil patrimonial. Introducción al derecho. Madrid: Tecnos.

Moliner, Maria. 1994. Diccionario de uso del español. Madryt: Gredos.

Nowacki, Józef, Tobor, Zygmunt. 2000. Wstep do prawoznawstwa. Kraków: Zakamycze.

Nowak, Joanna. 2011. Modalność deontyczna w języku prawa na przykładzie polskiego i hiszpańskiego kodeksu cywilnego. rozprawa doktorska, Uniwersytet im. Adama Mickiewicza w Poznaniu.

Nowakowska-Głuszak, Anna. 2011. Aplicación de la noción de visión del mundo en el análisis del lenguaje jurídico. Anuario de la Facultad de Derecho 29, ss. 631-644.

Nowakowska-Głuszak, Anna. 2012. "Między normą prawa a normą języka: zastosowanie narzędzi językoznawstwa kulturowego w analizie tekstów prawnych". [W:] Przekład - teorie, terminy, terminologia. Język a Komunikacja 30, red. Maria Piotrowska, Joanna DybiecGajer, 171-178. Kraków: Tertium.

Pawlik, Janusz. 2001. Selección de problemas de gramática española. Poznań: Wydawnictwo UAM.

Supera-Markowska, Maria. 2009. Zarys prawa hiszpańskiego $i$ polskiego. Warszawa: Wydawnictwo C. H. Beck.

Wilk-Racięska, Joanna. 2009. Od wizji świata do opisu językoznawczego w kategoriach lingwistyki kulturowej. Katowice: Wydawnictwo Uniwersytetu Ślaskiego.

Wilk-Racięska, Joanna. 1995. El artículo y la genericidad a la castellana. Katowice: Wydawnictwo Uniwersytetu Śląskiego.

Zieliński, Maciej. 2002. Wykładnia prawa. Zasady. Reguly. Wskazówki. Warszawa: LexisNexis. 